This item was submitted to Loughborough's Institutional Repository (https://dspace.lboro.ac.uk/) by the author and is made available under the following Creative Commons Licence conditions.

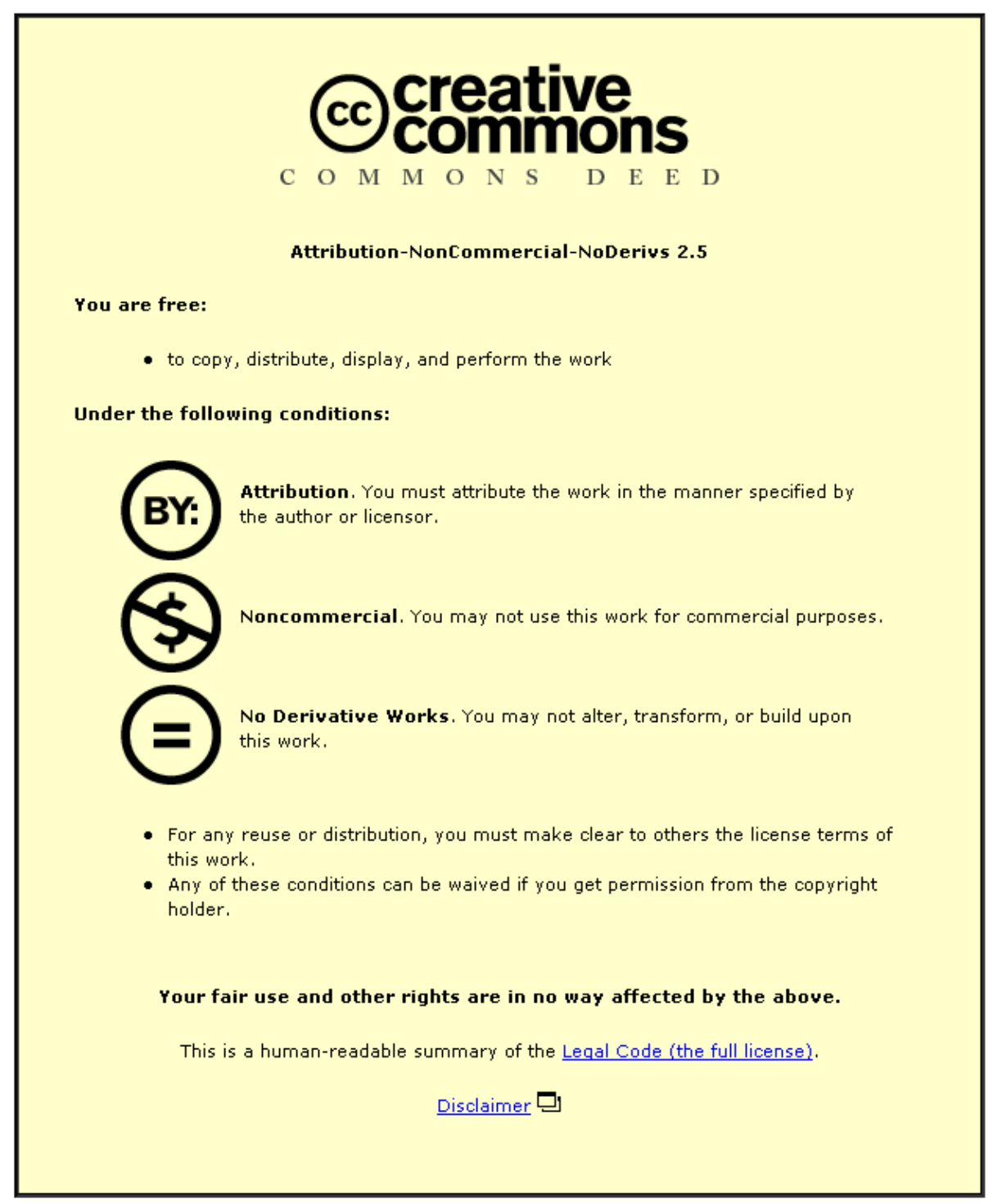

For the full text of this licence, please go to: http://creativecommons.org/licenses/by-nc-nd/2.5/ 
Cover sheet

Revised paper submitted to Journal of Construction Innovation

\section{INVESTIGATING THE INTEGRATION OF DESIGN AND CONSTRUCTION FROM A ‘LEAN’ PERSPECTIVE}

Bo Jørgensen, Ph.D., Consulting engineer, ConProC, Copenhagen, Denmark.

Email: BJ@conproc.com

Stephen Emmitt, Ph.D., Professor, Department of Civil and Building Engineering, Loughborough University, Leicestershire, LE11 3TU, UK

Email S.Emmitt@lboro.ac.uk

(Corresponding author)

Word count 7337

[Journal reference - Paper 440 CI Journal] 


\title{
INVESTIGATING THE INTEGRATION OF DESIGN AND CONSTRUCTION FROM A ‘LEAN’ PERSPECTIVE
}

\begin{abstract}
Purpose - Better integration of project processes has often been identified as the key issue regarding construction performance improvement. In some countries lean construction has become well established, although there appears to be considerable diversity in the interpretation of the concept. Lean construction initially focused on production aspects, but gradually design issues have started to receive more attention and integrating construction design and production processes from a lean perspective are beginning to be addressed. The purpose of the research was to identify some of the practical challenges underlying the implementation of approaches promoted as 'lean' and compare this with published research/theory.
\end{abstract}

Design/methodology/approach - Following an extensive review of the literature a multiple case strategy approach was used to explore the practical application of lean approaches to design and construction integration in an organisational setting. Summaries of the case studies, one from the USA and two from Denmark, help to highlight a number of pertinent issues facing practitioners and researchers.

Findings - Findings suggest that it is possible to identify a number of aspects that (in theory as well as in practice) both influence and, to various extents, limit the applicability of the lean philosophy to construction. Findings also help to emphasise the importance of a number of interdependent factors for achieving better integration, namely: value identification/specification; an appropriate project delivery framework; structuring and planning of delivery processes; transparency; management and leadership; learning; and the importance of local context.

Originality/value of paper - The findings provides an original contribution to the integration of design and construction activities from a lean perspective. The findings are generic and could be practically applied in a variety of contexts.

Keywords - Design/construction integration, lean philosophy, local context, project processes, value.

Paper type - Research paper 


\section{INTRODUCTION}

Integration has become, in different ways, a topical theme in the desire to improve the performance of architectural engineering and construction projects. A typical characteristic of construction is the separation (and fragmentation) between design and production, which in general is considered to be problematic (Bouchlaghem et al. 2004; Baiden et al. 2006) and publications have often argued that design and construction should, in one way or another, become better integrated (e.g. Brandon \& Powell 1984; Hughes 1989; Bröchner 1990; Koskela 2000; Anumba et al. 2000; Austin et al. 2001; Gray \& Hughes 2001; Bouchlaghem et al. 2004; Kimmance et al. 2004). Set alongside the literature on integration is the evolving field of lean construction, which in some countries is being heavily promoted as a means of construction supply chain improvement (Green \& May 2005; Jørgensen 2006). Taken at face value, it would appear that the lean philosophy could have the potential to better integrate design and construction activities.

Outside the construction field an extensive body of research has discussed lean production and lean manufacturing as a concept, examined examples of its practical application, and/or investigated specific issues addressed by lean production. Although heavily promoted (e.g. Womack et al. 1990; Cooper \& Slagmulder 1997; 1999) much research has been very critical regarding the credibility of the claims made by (especially) Womack et al. (1990) and several other proponents of 'lean'. Claims for the general superiority of lean production over all other systems or approaches have been convincingly rejected and a number of severe negative side effects of 'lean production' documented (Berggren 1992; 1993; Cusumano 1994; Jürgens 1995; Morris \& Wilkinson 1995; Williams et al. 1995; Katayama \& Bennett 1996; James-Moore \& Gibbons 1997; Benders \& van Bijsterveld 2000; Lewis 2000; Boyer \& Freyssenet, 2002; Cooney 2002). In general (critical) research has acknowledged that measures promoted under the label 'lean production/manufacturing' (or 'Toyota Production System') can be advantageous, depending on circumstances, and it has also substantially enriched the understanding of the impacts of 'lean production'. 
Characteristics of organisational concepts are that they a) leave room for interpretation and b) promise performance improvements. Organisation concepts, such as lean, that become management fashions share these to a high degree and tend to become decoupled from their original meanings as they are diffused, interpreted, translated, adopted and adapted (Abrahamson 1996; Kieser 1997). Research has suggested that this phenomenon has had significant impact on the diffusion of lean production, resulting not only in the term being de-coupled from its original meaning (into many different initiatives), but also in widespread rhetorical adoption often dominating substantial adoption (Benders 1999; Benders \& van Bijsterveld 2000). In spite of the variety of meanings ascribed the label 'lean' there appears to be a few largely common elements of these definitions/conceptions/interpretations:

- A focus on eliminating/reducing waste and sources of waste in relation to the delivery of artefacts or services that represent value to the end customer;

- End customer preference is adopted as the reference for determining what is to be considered value and what is waste;

- Management of production and supply chain from a (customer) demand pull approach;

- Approaching production management through focus on processes and flows of processes;

- An (at least to some degree) application of a system's perspective for approaching issues of waste elimination/reduction.

\section{APPLYING LEAN TO CONSTRUCTION}

The application of the 'new production philosophy' to construction was first discussed by Koskela (1992) and subsequently works within the field became known as lean construction. Koskela (2000) later argued in a $\mathrm{PhD}$ thesis that efforts to improve production (of physical artefacts, e.g. buildings and other structures) suffer from the absence of a general theory of production, and that such a theory would need to encompass three fundamental elements of transformation, process, and value. Koskela (2000) concluded that most production practice and research (in construction, 
manufacturing and other industries) has been dominated by a focus addressing production simplistically from a transformation perspective, with process and value generation aspects being under-emphasised. Although Koskela’s (2000) work is frequently cited, few publications have discussed the entire philosophy. Most publications address more specific issues of construction-orientated application from the framework now generally known as lean production; examples are Melles (1994), Seymour (1996), Koskela (2000, 2001, 2004), Picchi (2001) and Koskela \& Kagioglou (2005).

Since the 1990s lean has become increasingly prominent in construction, a development strongly influenced by the broader production and management debate, where lean has been a leading management fashion for around two decades. Lean construction has been embraced in the construction improvement debate and promoted as a 'new understanding of the construction process' that could (or would) bring substantial improvements in performance and stakeholder satisfaction. International attention increased with the publication of the Egan report Rethinking Construction (DETR 1998), which promoted lean thinking in construction as an approach that should be adopted to bring sustained performance improvement to the UK construction industry. The substantial argument was the claim that the lean thinking approach had delivered large improvements in manufacturing, in particular the motor vehicle industry, and where already applied in construction.

\section{Common definitions}

There is considerable confusion regarding what is meant by 'lean', 'lean construction' and 'lean design' in the extant literature, with many competing definitions and interpretations. Typically definitions are implicit (fully or partly), vague, interpretative and/or based on references that eventually lead back to popular management literature, most commonly Womack et al. (1990) and Womack \& Jones (1996). Neither of these frequently cited books provides a sufficiently clear and coherent definition of the lean concept. Thus it is not surprising that there is great diversity in the interpretation of what is meant by lean in building design and construction. Jørgensen et al. (2005) demonstrated that the management innovation lean construction appears to develop 
local meaning through processes of diffusion, interpretation, adaptation and adoption in accordance with mechanisms explained through previous research regarding diffusion of innovations (e.g. Rogers, 2003).

The lack of a common definition for lean construction and leanness has been discussed by Green \& May (2005) who found that lean construction and lean production are "variously understood as a set of techniques, a discourse, a 'socio-technical paradigm' or even a cultural commodity.” Based on an empirical study from the UK construction industry and interviews with authors of the Egan Report, Green \& May (2005) suggest that three models represent the practical adoption of lean in construction: a lean model of 'waste elimination', 'partnering', and 'structuring the context'. Green \& May (2005) found that their research findings indicated that lean construction, while highly diverse in interpretation and application, is inspired by lean production rather than just a direct copy of it (a relationship between lean production and lean construction previously proposed by Koskela et al. (2002)). It is concluded that the meaning of lean construction is continuously renegotiated within localised contexts (Green \& May 2005). Clearly there continues to be ongoing development in debate, understanding and practice within the field of lean construction, which appears to follow a pattern of some similarity to that of the development of debate on lean production.

In relation to lean construction, 'lean design' is considerably less discussed and investigated than production issues, notable exceptions being (Freire \& Alarcón 2002, Whelton 2004; Emmitt et al. 2004). While also lacking a universal definition, lean design in construction is used as referring to approaches, principles and methods for managing processes of design and/or of product development. Publications on design management in relation to lean construction generally adopt the term lean design or, emphasising that they are specifically addressing the management aspects, with the term lean design management. The lack of explicit or clear definitions of what is meant by lean design is no less noticeable than the missing clarity regarding the conception of lean construction. In most cases it is not clear when and if authors discuss 'lean design', 'lean design management' or e.g. 'design for lean construction' and hence it is not clear if such terms are used to describe different phenomena. 
The review of literature did not suggest that two (principally) different definitions for lean design and lean construction would be appropriate for the research. With a focus on enhancing (customer) value and eliminating/reducing waste from a system’s perspective, it can be argued that the lean philosophy and its basic elements address both design and production processes. However, the practical implications of applying a lean approach are naturally very different in the case of construction design than when compared to construction production/assembly. On the basis of findings and considerations discussed above, the research adopted the following working definition. Lean design and lean construction:

- Applies a systems’ perspective to enhance value and eliminate/reduce waste and drivers of waste in the construction project;

- Adopts customer (client/user/stakeholder) preference as the reference for determining what is to be considered value;

- Approaches design and construction management through a focus on processes and flows of processes;

- Adopts an understanding of design and construction/production activities from a perspective of three simultaneous conceptualisations: 1) transformation; 2) flow; and 3) value-generation;

- Manages design and construction/production processes with a (customer) demand-pull approach as far as this is applicable.

\section{(LEAN) DESIGN AND CONSTRUCTION INTEGRATION}

Principally, the lean philosophy promotes an integrated approach to designing and making, and some lean construction proponents have proposed that production should be understood as consisting of both designing and making (e.g. Koskela 2000; Ballard \& Zabelle 2000; Ballard 2002) but, all in all, a review of publications on lean construction suggests that terms are used in a large variety of ways and different notions of design and production appear to co-exist. For clarity, this paper will apply the traditional terminology and use the term production for the processes concerned with 
the physical making of what is specified through design. While it is important to be aware of differences in the terminology used, the need exists for specifying on a more concrete level what is understood by a lean approach to design/construction integration. In this paper integration of lean design and lean construction will be understood from the perspective of achieving a design/construction project team that works integrally in pursuit of a lean approach to project delivery.

The challenge from a research perspective is deciding on which aspects of integration to focus on. Taking the lean philosophy of value optimisation and waste minimisation and applying it to building design and construction it is possible to consider integration from four inter-related perspectives:

- Aspects of vertical and/or horizontal integration in the construction supply chain and in between construction delivery and the management of real estate facilities and related services. (e.g. Bröchner 1990, 2003; Haugen, 2000)

- Integration of information systems for product and processes, which is often approached through a strong IT orientation. (e.g. Anumba et al. 2000; Austin et al. 2000, 2002; Bouchlaghem et al. 2004; Kimmance et al. 2004).

- Integration of working practices and collaborative processes in the construction project organisation. (e.g. Austin et al. 2001, 2002; Baiden et al. 2006).

- Constructability, which is often dealt with from the perspective of specific practical advices for producing designs with a high level of constructability, e.g. the ‘design for assembly’ approach (Ferguson 1989; Griffith \& Sidwell 1995; Austin et al. 2001; Holroyd 2003).

Given the limitations of the research a decision was taken to focus on working practices and collaborative processes (third bullet point). However, as illustrated by the three case studies described below, practical pursuit of design/construction integration is influenced by a large number of contextual factors and other perspectives cannot be ignored. 
Baiden et al., (2006) have suggested that integration can be considered as "the merging of different disciplines or organisations with different goals, needs and cultures into a cohesive and mutually supporting unit”, and that integration in construction describes the introduction of "working practices, methods and behaviours that create a culture of efficient and effective collaboration by individuals and organisations”. They use the term 'integrated construction project team' to characterise "a highly effective and efficient collaborative team responsible for the design and construction of a project.” Integration here refers to the team bringing together "various skills and knowledge, and removes the traditional barriers between those with responsibility for design and construction in a way that improves the effective and efficient delivery of the project”. Thus Baiden et al., (2006) approach the theme of design/construction integration and team integration from the perspective of achieving integrative project processes and working practices. This is a feature shared by lean design/construction, which was decisive for the choice of adopting definitions and categorisations proposed by Baiden et al., (2006) as reference points for this research.

\section{RESEARCH METHODOLOGY}

The aim of the research was to study the initiatives and practical efforts applied in practice to better integrate lean design and lean construction. A multiple case strategy was adopted for exploring the practical application of lean approaches to design/construction integration in an organisational setting. Central to the research methodology was the ability to monitor projects over a long period of time to be able to study the design processes and their relationship to production. The methods used were:

- Non-participant observations of design team meetings, and when possible other project meetings;

- Analysis of project material (tendering and bidding documents, meeting minutes, correspondence etc.);

- Qualitative interviews with project participants. 
Three large projects (a residential and a rehab-housing project in Denmark and a health care project in California, USA) were studied over a 30 month period. These were selected because they represented projects in which lean principles were being implemented and to which the researcher could gain access. All three projects were, although in different ways, highly complex and represented three different approaches and strategies to procurement and to design/construction integration through lean application. While the Californian project was managed by the client under a designassist setup the Danish case projects were organised under two different design-build structures, one of which (Case 1) had a substantial element of partnering and initiatives to facilitate the early involvement of suppliers.

When the data collection period was finished the three case studies were analysed to see if common themes could be identified from the different practical approaches.

\section{THE CASE STUDIES}

Case 1 investigated the progress of the early design stages of a residential housing project in Denmark, which comprised 100 apartments and had a budget of approximately 67 million Euros. This was a design and build project, led by a large contractor for a large institutional client. The project was unique from the perspective of the participants in that is was (a), intended to be the first of a series of five housing projects carried out in cooperation by the same team for the same client and (b), there was a development strategy to systematically improve performance from one project to the next. Design and production management was expected to benefit from use of the Last Planner System of Production Control (Ballard 2000), interpreted locally and implemented as ‘trimmet byggeri’ (trimmed building). Furthermore, continuity of key participants in the project organisation and a high degree of repetition from one project to the next were to support lean efforts of systematically addressing waste and value from conceptual design to final completion of the fifth and last project. Due to a number of unexpected delays with the project it was only possible to observe the early stages of the first of the five projects. Despite this, sufficient data were collected to illustrate some of the challenges associated with integration. Practical difficulties were found 
with trying to involve the wider construction supply chain in lean initiatives, which appeared to hinder the desire for an integrated approach to the project.

Case 2 observed the design and early construction phases of a residential refurbishment project in Denmark, which comprised 112 housing units and had a budget of approximately 13 million Euros. This project had been divided into three sub-projects and the contractors had been chosen on the basis of competitive tendering for design and build services. The client was a non-profit housing corporation and since the project was funded by public funds it was subject to the rules relating to the procurement of publicly funded projects. On this project one of the contractors was implementing its lean design concept as a pilot project, which formed the focus of the research. This also involved the use of the Last Planner System (Ballard 2000), which although being the main lean tool used by the contractor, was not fully used by all participants during the monitoring period.

Case 3 was a major extension to an existing hospital and medical centre in California, USA, with a budget of approximately 44 million Euros. This project was a client-driven approach to integrated delivery through all project stages based on lean design and construction. The design and construction integration was addressed from the perspective of enhancing client and user value through the use of collaborative design and the application of design to target cost principles; a product development approach described by Cooper \& Slagmulder, $(1997,1999)$, and discussed in regard to AEC application by Jørgensen (2005) and Ballard (2006). The client was a non-profit network of hospitals and associated healthcare services. The major contributors to the project had experience of working together on previous projects and all were committed to collaborative working and lean principles. This was, however, the first time that the team had used design to target cost principles.

\section{Differences of interpretation and application}

In the context of this research the most important differences between the Danish and Californian lean initiatives concerned the diverse (local) interpretations of lean and the different levels of abstraction on which the construction organisations addressed lean 
implementation. While the Californian example represented a relatively holistic approach to lean implementation with the main emphasis on some fundamental ideas, the lean implementation at the Danish projects primarily focused on the application of a few specific tools and procedures, such as the Last Planner System. In comparison to the holistic approach of Case 3, the two Danish examples appeared to represent a rather narrow application of the lean philosophy. The difference in local interpretation and application of the lean concept makes it difficult to compare the three cases, but it was possible to identify some themes common to the case studies, which are described below.

\section{RESEARCH FINDINGS}

Each case study demonstrated a different approach to the application of the lean concept and integration of working practices, which supported the findings of the literature review. Analysis of all three case studies indicated that it is possible to identify a number of aspects that (in theory as well as in practice) both influence and, to various extents, limit the applicability of the lean philosophy to construction. This applies both to the more general level and also in relation to providing an appropriate means for design/construction integration. Although it was not possible, on the basis of the findings, to propose a general model, the case studies revealed some issues that appeared to be influential. These are summarised below under the following headings:

- $\quad$ Project value specification;

- Active client, user and stakeholder involvement;

- Decision and decision process transparency;

- Transparency regarding value/waste consequences of design decisions;

- Management of design iteration processes;

- Collaborative design with contractor/supplier involvement;

- Commitment from project participants (including suppliers);

- Project team learning. 


\section{Project value specification}

The importance of specifying (customer) value has been emphasised in publications that have dominated the lean debate, perhaps most noticeably by Womack \& Jones (1996) who promoted value specification as the first of five lean principles. Nevertheless, practical as well as theoretical aspects of how this principle can be applied have received little attention, despite the fact that the specification of 'end customer value' is anything but simple in the context of construction (Jørgensen 2006). All three cases illustrated the importance of thoroughly specified client and stakeholder value(s) if efforts to systematically enhance value and eliminate waste are to be realised in a broader perspective that encompasses both design and construction. The findings from the cases suggested that the specification of value must be made explicit to all stakeholders. Where the specified value represented a compromise between different stakeholder interests then the value specified must be sufficiently viable and supported by the participants to ensure the stability of decisions necessary for effective planning. Observations revealed that it was not always sufficient for the construction professionals to be informed about a client/user preference; understanding the circumstances or assumptions behind a preference/wish/demand was often essential.

The value specification process is likely to take a significant amount of time and effort, and it is necessary that the project delivery team, in addition to knowing what has been specified as value, understands the underlying factors and preconditions of individual stakeholder value, needs, interests etc. The project management and delivery team must understand the 'political arena' of the different stakeholder interests and the power/influence backing them. They must also allow sufficient time within the programme for the values to be explored and the project value to be agreed. This is consistent with the arguments put forward in the client briefing (e.g. Blyth \& Worthington 2001), value management (e.g. Kelly et al., 2004) and design management literature (e.g. Emmitt 2007).

\section{Active client, user and stakeholder involvement}

The role and active involvement of stakeholders was found to be central to the practical efforts of applying a lean perspective to integrating design and construction. This 
supports the literature arguing for effective involvement of clients and stakeholders for successful project completion (e.g. Brandon \& Powell, 1984). Often the lack of information or a response from project stakeholders became critical for progressing with project decisions. The significance of this is not exclusive to the application of lean, but represents a theme of general importance to effective project management in the AEC sector. In the case studies the successful application of a lean approach, with a systemic focus on value and waste and on flows of processes and transformations, was found to be highly dependent on the ability of those charged with managing the various aspects of the projects.

Of particular importance from a lean perspective is that late project changes can very easily result in significant waste. This may compromise value delivery, compared with what could have been achieved had the needs/wishes prompting the change been known or anticipated at an earlier juncture. Active client involvement and a meticulous briefing process are necessary for identifying the potential for uncertainty and hence helping to eliminate or at least mitigate the effects of such changes as argued in Emmitt et al., (2004).

\section{Decision and decision process transparency}

This theme is a key issue in several respects, not least when pursuing an integrated approach to design and construction. Information generated in 'upstream' project processes is decisive to the specification, planning and execution of downstream activities. There is also significant interdependence between subsystems where a decision regarding one sub-system can have a major influence on design and assembly processes of the others.

Establishing transparency regarding decisions, decision processes and their wider consequences (e.g. in terms of the impact on the amount of choice regarding decisions in later project stages) is a critical factor when pursuing an integrative approach to systematic value optimisation and waste reduction. It is important to ensure that transparency is achieved from the perspective of client, users and other stakeholders directly involved with the project. The findings of the case projects emphasised the 
importance of structuring the project for achieving an appropriate match between decision/approval processes and design processes. A particular challenge, it seemed, was to ensure that decisions and decision progress would appear sufficiently transparent to client, users and other stakeholders, especially those that were not construction professionals. Decision process transparency commonly created difficulties when previously 'fixed' decisions were subsequently challenged by some of the project parties.

\section{Transparency regarding value/waste consequences of design decisions}

This theme is closely connected to decision and decision process transparency. To pursue a lean approach and systematically address value/waste aspects in the project system it is necessary to establish transparency regarding the wider consequences of design decisions. Two case findings stand out as being central issues. First, that efficient contractor/supplier feedback requires a high level of detail in the preliminary design. This does not necessarily imply that effective feedback cannot be achieved before late design stages when basic parameters are fixed, but that considerable parts of the design will need to be worked through early in the process when it is still possible to use feedback for altering design concepts without compromising design intent. Second, that contractor/supplier knowledge and engagement contributed to both the improvement of client/customer/stakeholder value delivery and to the addressing of waste aspects related to later project stages. For the case projects a specific challenge was achieving efficient cost feedback at early stages of the design process. Design to target cost principles were applied in Case 3, where it was found that efficient cost feedback required a great level of detail in the design. This resulted in considerably more work in the early design phases compared to project where design to target cost principles was not applied.

\section{Management of design iteration processes}

From the value/waste understanding of the lean philosophy, design iteration will generate a lot of 'waste' through drafting, rework, examining possibilities never pursued etc. The question is not simply about minimising resources spent on design but (in principle) to manage design to deliver best possible value through project processes generating less waste over the system’s perspective. An important issue of lean design 
management is thus to enhance positive iteration while avoiding negative iteration (i.e. work that does not contribute to solutions and that could have been avoided). The case findings suggested that the two most fundamental aspects of managing design iteration is to enable positive design iteration on value delivery and to ensure that crucial parameters are not fixed too early to preclude positive improvements. Yet it is necessary to make sure that the parameters and specifications are fixed sufficiently early for the design and project progress to be efficiently managed. This is a considerable challenge for design managers, since achieving the correct balance will influence design quality and the financial viability of the project from the perspective of the design office. The clear identification of project value and active client/stakeholder participation is required here (a feature of case studies 2 and 3 where these issues were handled very differently and with very different results), a point constantly argued in the lean literature.

\section{Collaborative design with contractor/supplier involvement}

Collaborative working is a very wide theme, which involves a large number of interrelated issues; it is not just about the sharing of information, which is commonly mistaken for a collaborative approach. In addition to various aspects of coordination, collaborative design often has implications, such as the need for project participants to change their usual ways of working in order to enable effective interaction with others. Such changes may be perceived by project participants as significant (or threatening) and hence difficult to handle. This can have wider social and organisational implications (which are outside the scope of this paper). Achieving the sufficiently high degree of effective collaboration necessary to address value/waste issues in the wider project perspective requires considerable effort from project participants to actively participate in a large number of project processes - some regarding aspects of which individual participants' area of responsibility may be only marginally and indirectly affected. The case studies showed that effective collaborative design was challenged by difficulties of ensuring sufficient supplier feedback, and that this often required a high level of design detail in early project phases. Facilitation and leadership appeared to be crucial issues, not least for achieving effective communication between the construction professionals and other stakeholders, for example building users. Although it can be argued that 
collaborative design is an inevitable step in addressing value/waste aspects over the system's perspective - and thus throughout the supply chain - sociological perspectives of changing working procedures towards integrated efforts of lean application are yet to be addressed by research.

\section{Commitment from project participants (including suppliers)}

To address value and waste in a wider perspective and to avoid sub-optimisation, commitment from the whole supply chain is necessary, especially in an organisationally and technically complex design/production system such as construction projects. The findings of the case projects showed that a lack of engagement from individual organisations/project participants was a significant impediment to the application of lean strategies. It was strongly indicated that the issue of commitment is of central importance to the wider theme of design/construction integration. One can argue that this must be present from the very beginning of projects and that design and project managers must constantly stimulate the system to maintain a high degree of commitment.

\section{Project team learning}

Continuous improvement, systematic experimentation and continuous learning across all organisational and technical levels are important aspects of the lean philosophy, particularly as a means for trying to enhance customer value while reducing or eliminating waste. The importance of learning processes for successful project performance in construction (like other industries) has long been recognised and it has been argued that already at pre-project stages learning processes are influential in shaping project circumstances (Whelton 2004). The opportunity to discuss value via a lean-based project delivery strategy helped to stimulate exchanges of information/knowledge and thus enabled learning to take place. 


\section{PRACTICAL CONSIDERATIONS FOR INTEGRATING DESIGN AND CONSTRUCTION FROM A LEAN PERSPECTIVE}

The findings can be organised according to whether client-side or project delivery team (of which the client might be an important contributor) in principle is in position to ensure effective management of these processes and methods, as illustrated in Figure 1.

[Publisher to insert Figure 1 here]

The figure helps to illustrate that although the project is executed in an organisational setup consisting of the project delivery team as well as both the client and client side stakeholders, not all matters critical to value/waste orientated design/construction integration can be efficiently dealt with if approached in isolation within the project framework. Crucial issues affecting the overall project context must also be addressed on the level of individual organisations involved.

In considering the practical application of the findings, a number of inter-related process/methods appear to be central to helping to bring about integration with a lean project environment. First it is necessary to establish an appropriate project delivery framework for the project. This includes the establishment of incentives, agreements and resources (time, financial, human and organisational resources), as well as appropriate legal contracts to support the design/construction integration and an overall lean approach. The delivery framework also includes the organisation of the project and the structuring and planning of the design and delivery process. Central here is the composition of delivery team and its organisation, and project scheduling, planning and preparation processes.

Second, is the ability to identify value, specify and effectively communicate a common understanding of customer value, needs etc. and ensuring that participants have the support necessary for project continuity. This must be done transparently and openly including all decision-making related to social and technical matters, and the value/waste consequences of such decisions. 
The third point concerns management, leadership and learning. The ability to stimulate the project stakeholders into active involvement throughout the project is crucial. So too is supporting and stimulating project team learning and exchange of knowledge at all levels of project processes and at all relevant levels of the organisations involved.

It is important to emphasise that all of these issues need to be addressed throughout the project lifecycle. It was evident in the case studies that the failure to deal with one or more of the issues could compromise the overall efforts for design and construction integration.

Compared to the work of Baiden et al. (2006), who could not observe that seamless operation should be a fundamental requirement for integrated team performance and effective project delivery, the findings suggest that project process integration in pursuit of a 'leaner' approach is dependent on a number of different parameters, of which team organisation and management is but one.

\section{CONCLUSIONS}

Based on the findings of the case studies it appears that as a means for pursuing integration of design and construction processes the lean philosophy can be appropriate, but not in isolation. There are two caveats. First, the notion of the 'end customer' needs to be redefined to represent a range of construction stakeholders. Second, value needs to be defined with reference to the whole-life perspective in which a built artefact delivers its value and generates waste.

Ambiguity, vagueness and uncertainty over value aspects define the limit to which the lean philosophy can be applied in an integrated construction project system. The wider contextual issues, including structural, social and cultural aspects, also contribute to practical limitations regarding the extent to which a lean philosophy can be applied as a means for design/production process integration. 
The findings help to highlight the importance of project participants possessing a thorough understanding of the specific project context. This must be present at all levels of design and planning activities when pursuing integrated approaches to value enhancement and waste elimination. This appeared to be as important as the procurement approach adopted.

The research indicated that knowledge of the specified project, client, user and stakeholder value (and values) is likely to be insufficient for effective collaborative design and construction. A deeper understanding of the underlying contextual circumstances that define value and values will be necessary for ensuring efficient identification of suitable project decisions. This may add considerable complexity to project collaboration where individual project participants work in geographical, social and cultural contexts that are some distance (both physically and metaphorically) from the context of the environment being developed through construction. However, recognition of the issues raised in this research might help project participants to implement innovations such as lean design and lean construction to better suit their unique circumstances.

\section{References}

Abrahamson, E. (1996) Management Fashion. Academy of Management Review, Vol. 21 (1), pp. 254-285.

Anumba, C.J., Bouchlaghem, N.M., Whyte, J. and Duke, A. (2000) Perspectives on an integrated construction Project Model, International Journal of Cooperative Information Systems, 9(3), 283-313.

Austin, S., Baldwin, A. and Li, B. (2000) Analytical design planning technique (AdePT): a dependency structure matrix tool to schedule the building design process. Construction Management and Economics, Vol. 18(2) December, pp. 173-182.

Austin, S. A., Baldwin, A.N., Hammond, J., Murray, M., Root, D., Thomson, D. and Thorpe, A. (2001) Design Chains: a handbook for integrated collaborative design, Thomas Telford Publishing, London.

Austin, S. A., Baldwin, A.N. and Steele, J.L. (2002) Improving building design through integrated planning and control. Engineering, Construction and Architectural Management, Vol. 9(3), pp. 349-358. 
Baiden, B.K., Price, A.D.F. and Dainty, A.R.J. (2006) The extent of team integration within construction projects, International Journal of Project Management, 24(1), 1323.

Ballard, G. (2000) The Last Planner System of Production Control, PhD Thesis, University of Birmingham, UK.

Ballard, G. (2002) Managing work flow on design projects: a case study, Engineering, Construction and Architectural Management, 9(3), 284-291.

Ballard, G. (2006) Target Costing in Construction. $1^{\text {st }}$ International Construction Speciality Conference. Calgary, Alberta, Canada, May 2006.

Ballard, G. and Zabelle, T. (2000) Lean Design: Process, Tools, \& Techniques, White Paper \#10, Lean Construction Institute, USA, October 2000.

Benders, J. (1999) Tricks and trucks: a case study of organization concepts at work. The International Journal of Human Resource Management, Vol. 10(4), pp. 624-637.

Benders, J. and van Bijsterveld, M. (2000) Leaning on lean: the reception of a management fashion in Germany. New Technology, Work and Employment, Vol. 15:1, pp. 50-64.

Berggren, C. (1992) Alternatives to Lean Production: Work Organization in the Swedish Auto Industry. ILR Press, Ithaca, New York.

Berggren , C. (1993). Lean Production - The End of History? Work, Employment and Society, Vol. 7, No. 2, 1993.

Blyth, A. and Worthington, J. (2001) Managing the Brief for Better Design, Spon Press, London.

Bouchlaghem, D., Kimmance, A.G. and Anumba, C.J. (2004) Integrating product and process information in the construction sector, Industrial Management \& Data Systems, 104(3), 218-233.

Boyer, R. and Freyssenet, M. (2002) The productive models: the conditions of profitability. Palgrave MacMillan, New York.

Brandon, P.S. and Powell, J.A. (1984) Quality and Profit in Building Design. E. \& F.N. Spon, London.

Bröchner, J. (1990) Impacts of information technology on the structure of construction, Construction Management and Economics, 8, 205-218.

Bröchner, J. (2003) Integrated Development of Facilities Design and Services. Journal of Performance of Constructed Facilities, February 2203, pp. 19-23. 
Cooney, R. (2002) Is "lean” a universal production system?: Batch production in the automotive industry. International Journal of Operations \& Production Management, Vol. 22(10) pp. 1130-1147.

Cooper, R. and Slagmulder, R (1999) Supply Chain Development for the Lean Enterprise. The Institute of Management Accountants Foundation for Applied Research, Montvale New Jersey, USA. Productivity Press, Portland, Oregon.

Cooper, R. and Slagmulder, R (1997) Target Costing and Value Engineering. The Institute of Management Accountants Foundation for Applied Research, Montvale New Jersey, USA. Productivity Press, Portland, Oregon

Cox, A. and Ireland, P. (2002) Managing construction supply chains: the common sense approach, Engineering, Construction and Architectural Management, 5(6), 409-418.

Cusumano, M.A. (1994) The Limits of “Lean”. Sloan Management Review, Summer 1994, pp. 27-32.

DETR (1998) Rethinking Construction, Department of the Environment, Transportation and the Regions, London.

Emmitt, S., Sander, D. and Christoffersen, A.K. (2004). Implementing Value through Lean Design Management. 12th Annual Conference of The International Group for Lean Construction, Helsingør, Denmark.

Emmitt, S. (2007) Design Management for Architects, Blackwell Publishing, Oxford.

Ferguson, I. (1989) Buildability in practice. Mitchell Publishing Company Limited, London.

Freire, J. and Alarcón, L.F. (2002) Achieving Lean Design Process: Improvement Methodology. Journal of Construction Engineering and Management, Vol. 128(3), pp. 248-256.

Gray, C. and Hughes, W. (2001) Building Design Management, ButterworthHeinemann. Oxford.

Green, S.D. and May, S.C. (2005) Lean construction: arenas of enactment, models of diffusion and the meaning of 'leanness', Building Research \& Information, 33(6), 498511.

Griffith, A. and Sidwell, A.C. (1995) Constructability in Building and Engineering Projects. MacMillan Press, London.

Haugen, T.I. (2000) An Integrated Process from Design to Facilities Solutions. In: Proceedings of CIB W70 International Symposium on Facilities Management and Asset Maintenance, 15-17 November 2000, Brisbane, Australia. 
Holroyd, T.M. (2003) Buildability. Thomas Telford, London.

Hughes, W.P. (1989) Organizational Analysis of Building Projects, PhD Thesis, Liverpool Polytechnic, UK.

James-Moore, S.M. and Gibbons, A. (1997) Is lean manufacture universally relevant? An investigative methodology. International Journal of Operations \& Production Management, Vol. 17(9), pp. 899-911.

Jørgensen, B. (2005) Designing to target cost: one approach to design/construction integration, In: Designing Value (Ed. Emmitt, S. \& Prins, M. 2005), CIB Publication 307, DTU, Denmark, 311-319.

Jørgensen (2006) Integrating Lean Design and Lean Construction: Processes and Methods. Ph.D. Thesis, Technical University of Denmark, Department of Civil Engineering, 286p (available for download at: http://orbit.dtu.dk/app).

Jørgensen, B., Emmitt, S., and Ballard, G. (2005) Divergent focus in the application of lean construction: examples from Denmark and California, in Proceedings of the $13^{\text {th }}$ Annual Conference of the International Group for Lean Construction (IGLC-13), Sydney, July, pp. 395-403.

Jürgens, U. (1995) Lean Production in Japan: Myth and Reality. In Littek, W. \& Charles, T. (eds.) (1995) The New Division of Labour: Emerging Forms of Work Organisation in International Perspective, pp. 349-366. Walter de Gruyter, New York.

Katayama, H. and Bennett, D. (1996) Lean production in a changing competitive world: a Japanese perspective. International Journal of Operations \& Production Management, Vol. 16(2), pp. 8-23.

Kelly, J., Male, S.,and Graham, D. (2004) Value Management of Construction Projects, Blackwell Publishing, Oxford.

Kieser, A. (1997) Rhetoric and Myth in Management Fashion. Organization, Vol. 4(1), pp. 49-74.

Kimmance, A.G., Anumba, C.J., Bouchlaghem, D.M. and Baldwin, A.N. (2004) The application of information modelling methodologies: the HIPPY approach to integrated project modelling, International Journal of Computer Applications in Technology, 20, 62-77.

Koskela, L. (1992) Application of the New Production Philosophy to Construction, Tech. Report No. 72, CIFE, Stanford University, CA.

Koskela, L. (2000) An Exploration Towards a Production Theory and its Application to Construction, VTT, Espoo, Finland. 
Koskela, L. (2001) On New Footnotes to Shingo. Proceedings for The $9^{\text {th }}$ Annual Conference on Lean Construction. Singapore.

Koskela, L. (2004) Moving on - beyond lean thinking. Lean Construction Journal Vol. 1(1), October.

Koskela, L., Howell, G., Ballard, G. and Tommelein, I. (2002) The foundations of lean construction, In Hellingsworth, B., Best, R. \& de Valence, G. (eds.): Design and Construction: Building in Value, Elsevier, 211-226.

Koskela, L. and Kagioglou, M. (2005) On the Metaphysics of Production. In: Proceedings of the $13^{\text {th }}$ Annual Conference of the International Group for Lean Construction, Sydney, July.

Lewis, M.A. (2000) Lean production and sustainable competitive advantage. International Journal of Operations \& Production Management, Vol. 20(8), pp. 959978.

Melles, B. (1994) What do we mean by lean production in construction? Proceedings of the $2^{\text {nd }}$ Workshop on Lean Construction (IGLC-2), Santiago de Chile.

Morris, J. and Wilkinson, B. (1995) The Transfer of Japanese Management to Alien Institutional Environments. Journal of Management Studies, Vol. 32:6 (ed.), pp. 719730, November 1995.

Picchi, F. (2001) System View of Lean Construction Application Opportunities. Proceedings of The $9^{\text {th }}$ Annual Conference on Lean Construction. Singapore.

Rogers, E. M. (2003) Diffusion of Innovations (Fifth edition), Free Press, New York.

Seymour, D. (1996) Developing Theory in Lean Construction. Fourth Annual Conference of The International Group for Lean Construction (IGLC-4), Birmingham, UK.

Whelton, M. (2004) The Development of Purpose in the Project Definition Phase of Construction Projects - Implications for Project Management, PhD Thesis, University of California, Berkeley.

Williams, K., Haslam, C., Johal, S., Williams, J., Adcroft, A. and Willis, R. (1995) Management Practice or Structural Factors: The Case of America versus Japan in the Car Industry. Economic and Industrial Democracy, Vol. 16, pp. 9-37.

Womack, J.P. and Jones, D.T. (1996) Lean Thinking: banish waste and create wealth in your corporation, Simon \& Schuster, New York.

Womack, J.P., Jones, D.T. and Roos, D. (1990) The Machine That Changed the World: The Story of Lean Production, Harper Business, New York. 